\title{
Priapism as Presenting Manifestation of Germ Cell Tumor in a Child
}

\author{
Orhan OZBEK ${ }^{1}$, Yavuz KOKSAL ${ }^{2}$, Osman KOC ${ }^{1}$, Cuneyt KARAGOL ${ }^{2}$, Seda OZBEK ${ }^{3}$, Mehmet KILIC \\ ${ }^{1}$ Selcuk University Meram Faculty of Medicine, Department of Radiology \\ ${ }^{2}$ Selcuk University Selcuklu Faculty of Medicine, Department of Pediatric Oncology \\ ${ }^{3}$ Konya Training and Research Hospital, Department of Radiology \\ ${ }^{4}$ Selcuk University Meram Faculty of Medicine, Department of Urology, Konya, TURKEY
}

\begin{abstract}
Priapism, defined as prolonged and persistent erection of the penis without sexual stimulation, is rarely seen in children. We report a 2-year-old boy who was admitted with priapism with a history of the perineal trauma. Doppler ultrasonography revealed signs of high-flow priapism. Magnetic resonance imaging revealed an intrapelvic mass beside the root of the penis. The serum alpha-fetoprotein level was $54.600 \mathrm{ng} / \mathrm{ml}$ (Normal range: 0-9 $\mathrm{ng} / \mathrm{ml})$. Tru-cut biopsy was performed and endodermal sinus tumor was diagnosed. At the fourth day of chemotherapy, the penis became progressively less turgid and soft. After the first cycle chemotherapy, priapism had completely resolved.
\end{abstract}

Keywords: Children, Endodermal sinus tumor, Priapism

\section{ÖZET}

\section{Bir Çocukta Priapizm ile Prezente Olan Germ Hücreli Tümör}

Seksüel uyarı olmaksızın peniste ereksiyon halinin olması durumu olarak tanımlanan priapizm, çocuklarda nadir görülür. Perineal travma öyküsü olan 2 yaşında erkek hasta priapizm yakınması ile başvurdu. Dopler ultrasonografisinde yüksek akımlı priapizm tanısı konuldu. Manyetik rezonans görüntüleme yönteminde penis köküne uzanım gösteren intrapelvik kitle saptandı. Alfa fötoprotein düzeyi $54.600 \mathrm{ng} / \mathrm{ml}$ (Normal aralı: 0-9 ng/ml) idi. Tru-cut biyopsi uygulanan hastaya endodermal sinüs tümörü tanısı konuldu. Kemoterapinin 4. günü penisteki sertlik yumuşamaya başladı ve birinci kütr kemoterapi sonrasında tamamen kayboldu.

Anahtar Kelimeler: Çocuk, Endodermal sinüs tümörü, Priapizm 


\section{INTRODUCTION}

Priapism, a urological emergency, refers to a persistent erection not accompanied by sexual desire or stimulation, usually lasting for $>6$ hours and typically involving only the corpora cavernosa. This condition has many different causes. ${ }^{1}$ In children, the majority of children with priapism, however, are those with sickle cell disease although a number of different etiologies have been reported. ${ }^{2,3}$ In some malignancy disease such as leukemia, priapism may be as a presentation symptom. Herein, we report an endodermal sinus tumor case presented with priapism.

\section{CASE}

A 2-year-old boy with a history of perineal trauma was admitted with painless rigid erection of 25 days. Physical examination revealed a painless rigid erection. Penile doppler ultrasonography revealed signs of high-flow priapism. The peripheral blood count showed a hemoglobin level of 12.4 $\mathrm{g} / \mathrm{dl}$, a hematocrit value of $39.3 \%$, platelet count of $362.000 / \mathrm{mm}^{3}$ and a white blood cell count of $8.000 / \mathrm{mm}^{3}$ with normal differential. The serum biochemistry was normal except for a slightly elevated lactate dehydrogenase level (470 U/L, Normal range: 98-192). Hemoglobin electrophoresis was normal. Abdomen magnetic resonance imaging revealed a mass lesion placed in the right pelvis, which made invasion to iliac bone, rectum, iliopsoas muscle, muscles of proximal tigh and penil stump and was contrasted heterogenously with contrast dye (Figure 1a and 2b). Chest X-ray and thorax computed tomograhy showed numerous nodules located in the lungs parenchyma. The serum alpha-fetoprotein level was $54.600 \mathrm{ng} / \mathrm{ml}$ (Normal range: $0-9 \mathrm{ng} / \mathrm{ml})$. Tru-cut biopsy was performed from the pelvic mass and endodermal sinus tumor was diagnosed. The chemotherapy including cisplatin, etoposide and bleomycin was given. At the fourth day of chemotherapy, the penis became progressively less turgid and soft. After the first cycle chemotherapy, priapism had completely resolved.

\section{DISCUSSION}

Priapism is the occurrence of any persistent erection for more than six hours duration in the absence of sexual stimulation. There are two categories of priapism: low-flow and high-flow. Low-flow type of priapism is the result of blood being trapped in the erection chambers and it often occurs without a known cause in men who are otherwise healthy, but also affects men with sickle cell disease and leukemia. The other type, high-flow type of priapism, is more rare than low-flow and usually less painful. It is the result of a ruptured artery from an injury to the penis or the perineum (area between the scrotum and anus), which prevents blood in the penis from circulating normally. ${ }^{1-3}$
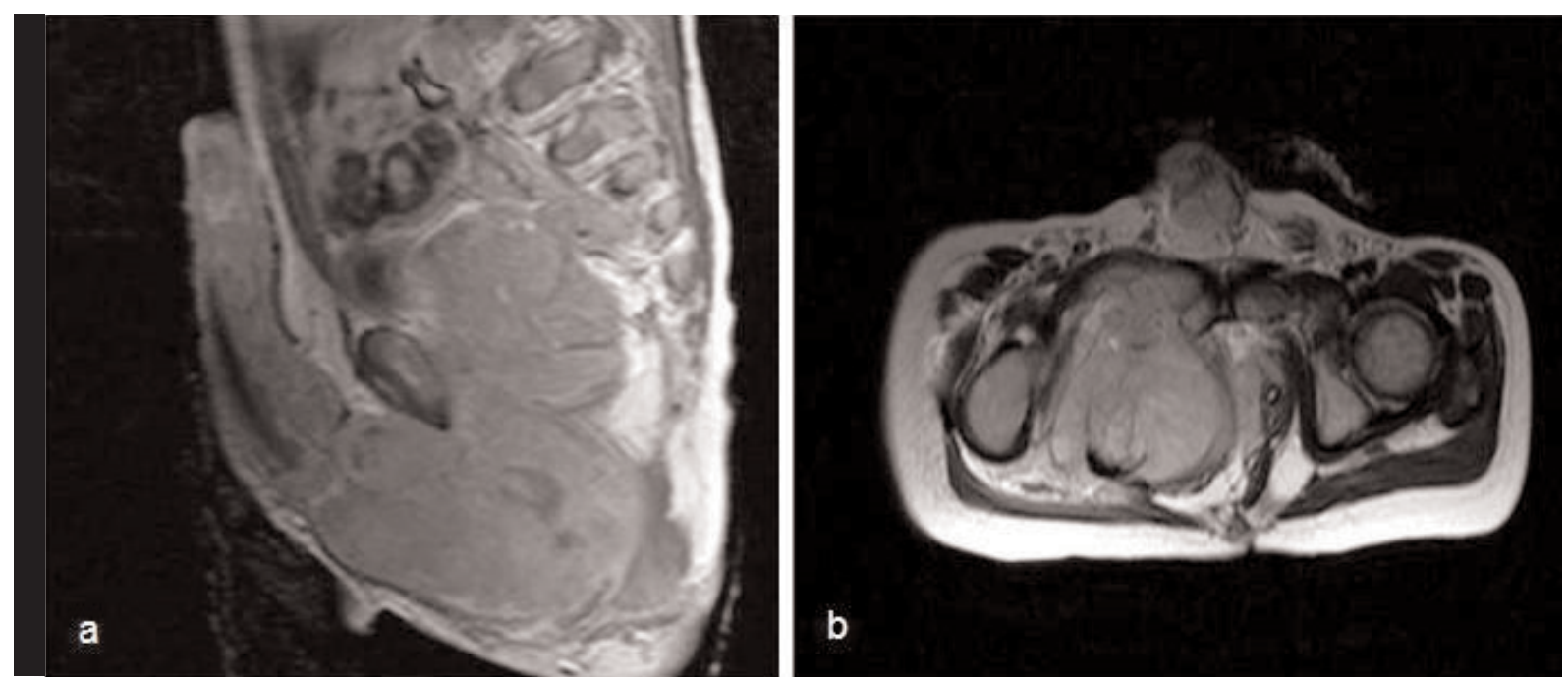

Figure 1. $T 1$ weighted sagittal image with contrast (a) and T2 weighted axial image (b) show a mass lesion placed in the right pelvis, which made invasion to iliac bone, rectum, iliopsoas muscle, muscles of proximal tigh and penil stump and was contrasted heterogenously with contrast dye. 
Causes of priapism are different medications, hematologic diseases (sickle cell anemia, leukemia, thalasemia, multiple myeloma), metabolic disease (amyloidosis, gout, Fabry disease, diabetes), infectious, neurologic diseases (myopathies, transverse myelitis), trauma (the spinal cord or genital area), and tumor (especially perineal masses). ${ }^{3}$

Various solid tumors including bladder and prostate cancer, renal cell cancer have been associated with priapism are well known. Malignant infiltration may obstruct venous drainage, thereby promoting stasis and thrombosis in the tissues. Specific chemotherapy and radiotherapy may be helpful in such cases. ${ }^{1}$ In children, leukemia is the majority cause of priapism due to malign diseases..$^{4-9}$ In a report by Krawczuk-Rybak et al. ${ }^{10}$, priapism was reported in a child with endodermal sinus tumor arising in the prostate. The priapism subsided after the second cycle, while the tumour and the metastases showed a good response.

The goal of all treatment is to make the erection go away and preserve future erectile function. Treatment options include: ice packs, surgical ligation (used in cases where an artery has been ruptured), intracavernous injection (used for low-flow priapism), surgical shunt (used for low-flow priapism, a shunt is a passageway that is surgically inserted into the penis to divert the blood flow and allow circulation to return to normal) and aspiration. ${ }^{1}$

In our patient, he had a history of the perineal trauma and was admitted priapism. Magnetic resonance imaging revealed an intrapelvic mass beside of the root of the penis. The serum alpha-fetoprotein level was high. After tru-cut biopsy, endodermal sinus tumor was diagnosed. At the fourth day of chemotherapy, the penis became progressively less turgid and soft.

In conlusion, priapism occasionally can be the presentation of hematological malignancies in children. To our knowledge, it has been reported the second case in children with endodermal sinus tumor. The goal of the treatment of priapism should be the prevention of erectile dysfunction and conservative management such as chemotherapy might be adequate for malignancy related with priapism in children.

\section{REFERENCES}

1. Keoghane SR, Sullivan ME, Miller MAV. The aetiology, pathogenesis and management of priapism. BJU International 90: 149-154, 2002.

2. Dewan PA, Tan HL, Auldist AW, Moss DI. Priapism in childhood. Br J Urol 64: 541-545, 1989.

3. Majeed S, Schor JA, Jacobson S, Jagoda A, Mahadeo R. Refractory priapism of unknown etiology in a pediatric patient. Pediatr Emerg Care 16: 347-351, 2000.

4. Yildiz I, Ozşahin H, Ozbek S. Priapism in a child with acute lymphoblastic leukemia. Acta Paediatr Scand 80: 553-554, 1991.

5. Gumruk F, Hiçsónmez G, Ozsoylu S, Gurgey A, Tuncer AM. High-dose methylprednisolone for the treatment of priapism in childhood leukemia. Pediatr Hematol Oncol 8: 367-368, 1991.

6. Bhatia P, Arya LS, Chinnappan D, Choudhry VP, Pati $\mathrm{H}$. Priapism in chronic myelogenous leukemia. Indian $J$ Pediatr 59: 130-132, 1992.

7. Mentzel HJ, Kentouche K, Doerfel C, Vogt S, Zintl F, Kaiser WA. High-flow priapism in acute lymphatic leukaemia. Pediatr Radiol 34: 560-563, 2004.

8. Werther R, Oakley E, Heath JA. Priapism as a presentation of T-cell acute lymphoblastic leukaemia in a child. Emerg Med Australas 16: 425-427, 2004.

9. Castagnetti M, Sainati L, Giona F, Varotto S, Carli M, Rigamonti W. Conservative management of priapism secondary to leukemia. Pediatr Blood Cancer 51: 420-423, 2008.

10. Krawczuk-Rybak M, Muszynska-Roslan K, Olenski J, Leszczynska E, et al. Priapism as the first sign of a pelvic tumour in a two-and-a-half-year-old boy. Med Pediatr Oncol 36: 503-504, 2001.

\author{
Correspondence \\ Dr. Yavuz KÖKSAL \\ Selçuk Üniversitesi, Meram Tıp Fakültesi \\ Pediatrik Onkoloji Bilim Dalı \\ Meram, Konya / TURKEY \\ Tel: $\quad$ (+90.332) 2236941 \\ Fax: (+90.332) 2236182 \\ E-mail: yavuzkoksal@yahoo.com
}

